\title{
COMPETITIVENESS OF THE SINGAPORE ECONOMY
}


This page is intentionally left blank 


\title{
COMPETITIVENESS OF THE SINGAPORE ECONOMY
}

\section{A Strategic Perspective}

\author{
Edited by \\ TOH MUN HENG \\ TAN KONG YAM
}

SINGAPORE UNIVERSITY PRESS

NATIONAL UNIVERSITY OF SINGAPORE 
(C) 1998 Singapore University Press

Yusof Ishak House, National University of Singapore

10 Kent Ridge Crescent, Singapore 119260

and

World Scientific Publishing Co. Pte. Ltd.

PO Box 128, Farrer Road, Singapore 912805

USA office: Suite 1B, 1060 Main Street, River Edge, NJ 07661

UK office : 57 Shelton Street, Covent Garden, London WC2H 9HE

ISBN 9971-69-214-7 (Case)

9971-69-221-X (Paper)

\begin{abstract}
All rights reserved. No part of this publication may be reproduced, stored in a retrieval system, or transmitted, in any form or by any means, electronic, electrical, chemical, mechanical, optical, photocopying, recording or otherwise, without the prior permission of the copyright holders.
\end{abstract}




\section{CONTENTS}

Acknowledgements .................................................................... vii

About the Contributors ........................................................... ix

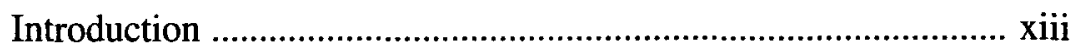

\section{PART I MACROECONOMIC STRATEGIES}

Chapter 1 The Macroeconomic Perspectives of Competitiveness

Tan Kong Yam and Toh Mun Heng .................. 3

Chapter 2 Technological Policy and National

Competitiveness

Lawrence Loh 40

\section{PART II SECTORAL CONCERNS}

Chapter 3 Maintaining Singapore as a Major Shipping and Air Transport Hub Anthony Chin and Jose Tongzon

Chapter 4 Upgrading Singapore's Manufacturing Industry Wong Poh Kam

Chapter 5 The Construction Industry: Restructuring for Competitiveness

Toh Mun Heng. 143

Chapter 6 Maintaining Competitiveness in New Age Tourism Wong Poh Poh. 178

Chapter $7 \quad$ Strategies for Financial Sector Development Lim Guan Hua 


\section{PART III SOCIAL \& CULTURAL PERSPECTIVES}

Chapter 8 Entrepreneurship and SMEs in the Singaporean Context

Björn Bjerke ....................................................... 249

Chapter 9 Globalisation and the Social Fabric of Competitiveness

Ho Kong Chong ................................................. 294

Chapter 10 Human Resource Management for the

New Competitive Environment

William Koh ..................................................... 312 


\section{ACKNOWLEDGEMENTS}

We would like to express our gratitude to the participants of the "Workshop on the Competitiveness of the Singapore Economy" held on the 9 December 1997, for their valuable comments and suggestions to revise and improve the chapters in this volume.

We are thankful to the Department of Business Policy (NUS), Centre for Management of Technology (NUS) and Singapore Confederation of Industries (SCI) for jointly organising the "Symposium on the Competitiveness of the Singapore Economy" held on 8 January 1998, to enable the authors to share their research findings with researchers and practitioners from the private and public sectors. We are grateful to Mr Robert Chua, the President of SCI, and Professor Shih Choon Fong, the Deputy Vice Chancellor of the NUS, for their welcoming addresses and support for the symposium.

We are also thankful for financial support provided by National University of Singapore (NUS) Research Grant (RP3972035) in conducting the research project.

Last but not the least, we like to thank Ms Rittu Khattar, Ms Sally Han, Mdm Teo Woo Kim, Ms Woo Ka Meng and Ms Lim Sin Ying for their patience and speedy efforts in providing editorial and word-processing assistance. 
This page is intentionally left blank 


\section{ABOUT THE AUTHORS}

Anthony T.H. Chin is Sub-Dean of the Faculty of Arts and Social Sciences and Senior Lecturer with the Department of Economics and Statistics at the National University of Singapore (NUS). His current areas of research include financing and cost recovery of transport infrastructure investments, regional port and airport competition, use of economic instruments and externalities from land transport and the impacts of road pricing on travel behaviour. $\mathrm{He}$ is also the Principal Researcher, Centre for Transportation Research at the Faculty of Engineering, NUS, Council Member of the Land Transport and Economic Development Committee of the Transportation Research Board of the USA, and Member of the Air Transport Research Group in Vancouver, Canada. He has been a consultant to various institutions such as Singapore Airlines, Port of Singapore Authority, the Automobile Association of Singapore and UNDP.

Björn Bjerke, a Scandinavian, has travelled widely and he has worked at several universities. Since 1991 he has held a position as a Senior Teaching Fellow at the National University of Singapore. Bjerke's main interests are entrepreneurship and cross-cultural studies. He has published several books on these subjects.

Ho Kong Chong is a senior lecturer in the Department of Sociology at NUS. Dr Ho received his doctorate from University of Chicago. He recently co-authored City-States in the Global Economy: Industrial Restructuring in Hong Kong and Singapore (Westview, 1997), and is co-editor of Culture and the City in East Asia (Oxford, 1997). Dr Ho is current a resource person for the Government Parliamentary Committee for National Development. $\mathrm{He}$ is also a member of the Advisory Panel on Youth Research, National Youth Council, and a member of the Publications Advisory Panel, Ministry of Information and the Arts.

William Koh is a Senior Lecturer in the Department of Organisational Behaviour at the Faculty of Business Administration, NUS. His research interests are in the areas of leadership, motivation, job design, stress management, human resource management, and general management. His work has been published in the Journal of Organisational Behaviour, Research and Practice in Human Resource Management, International Journal of Human Resource Management, and various international Conference Proceedings. Besides undergraduate teaching in NUS, Dr Koh also teaches at the various Executive Development Programmes organised 
by the Faculty of Business Administration. He has also done consulting work with various organisations around the region such Motorola, Johnson and Johnson, and the Singapore General Hospital.

Lawrence Loh is currently Vice-Dean of the Faculty of Business Administration, NUS. He received a $\mathrm{PhD}$ from Massachusetts Institute of Technology (MIT) in the field of information systems. He has published in internationally-refereed journals such as Management Science, Journal of Business Research, Information Systems Research, Journal of Management Information Systems, etc. Dr Loh has been a consultant to many well known international companies like IBM and Anderson Consulting (USA), as well as government agencies like National Science \& Technology Board (NSTB), National Computer Board in Singapore. He is presently in the National Productivity \& Quality Council and contributes as a resource person for the Committee on Singapore's Competitiveness.

Lim Guan Hua is currently a lecturer in the Graduate School of Business and the Department of Finance and Accounting, Faculty of Business Administration, NUS. He has a PhD in finance from the Wharton School, University of Pennsylvania. Dr Lim's research interests are varied and include the IPO market, cost \& profit efficiencies of banks, operations \& behaviour of financial markets, gray marketing, warranties, SMEs, and signalling \& game theory. His papers have been or will be published in the Journal of Business Finance and Accounting, Journal of Global Marketing, Review of Pacific-Basin Financial Markets and Policies, Singapore Management Review, and the SES Journal.

Tan Kong Yam is the Head, Department of Business Policy, Faculty of Business Administration at NUS. He is a graduate of Princeton and Stanford University. Prior to joining NUS, he has worked at the Hoover Institution, World Bank, the Monetary Authority of Singapore, and was the Director of Research at the Ministry of Trade and Industry in Singapore. His research interests are in international trade and finance, growth and development in the Asia Pacific region and economic reforms in China. He has consulted for many organisations including Citibank, IBM, ATT, BP and Mobil, etc. Currently, he is an economic consultant to the Ministry of Trade and Industry and a resource person for the government Committee for Singapore's Competitiveness.

Toh Mun Heng is an Associate Professor in the Department of Business Policy, NUS. He obtained his doctoral degree in Economics and Econometrics from the University of London, London School of Economics. His research interests and publications are in the areas of econometric modelling, input-output analysis, international trade and investment, manpower studies, transportation economics and household 
economics and development strategies for emerging economies in the Asia Pacific. He has been engaged as an economic consultant by international agencies such as the UN ESCAP, Asian Development Bank and ASEAN Secretariat, private companies and governmental ministries. Currently, he is an economic consultant to the Ministry of Trade and Industry and a resource person for the government Committee for Singapore's Competitiveness.

Jose L. Tongzon is a Senior Lecturer at the Department of Economics and Statistics, NUS. He specialises in international economics and maritime transport. Areas of research interest include ASEAN economies, transitional economies of Southeast Asia, and port efficiency. Before joining NUS, Dr Tongzon was Chief Economist of the Port of Melbourne Authority and worked as an academic and public servant in Australia and the Philippines for several years. At NUS he has published articles in the area of port performance, efficiency and international benchmarking for such journals as Transportation Research and Maritime Policy and Management. He is an active member of the Chartered Institute of Transport (CIT) and International Association of Maritime Economists (IAME).

Wong Poh Kam is an Associate Professor at the Faculty of Business Administration, NUS. He is currently the director of a research centre, the Centre for Management of Technology (CMT), and deputy director of the Graduate School of Business. He obtained his doctoral degree from the Massachusetts Institute of Technology. He has consulted widely for international agencies such as the World Bank/EDI, Asian Development Bank, UNESCAP and ASEAN Secretariat, various government agencies in Singapore such as EDB, NSTB, NCB and TDB, as well as numerous private companies in the region such as Southern Steel (Malaysia), HP Singapore and Singapore Telecoms. His current research interests include Management of Technological Innovation, Technology Strategies of East Asian Firms, National Science and Technology Policy, and National Information Infrastructure Policy.

Wong Poh Poh is an Associate Professor in the Department of Geography, NUS. He has a $\mathrm{PhD}$ in geography from McGill University and was trained as a coastal geomorphologist. Over the last decade, he has extended his research to coastal tourism in Southeast Asia, Taiwan and Reunion Island. He initiated and taught a course on Geography of Tourism for nearly 20 years and currently offers a new course on Tourism in Southeast Asia. He published widely on geography education, coastal geomorphology, tourism and coastal zone management and is the author of "Coastal Tourism in Southeast Asia" (1991) and editor of "Tourism vs. Environment: the Case for Coastal Areas" (1993). He has served as consultant to local and international organisations on environmental impact assessment, coastal tourism development and coastal zone management. 
This page is intentionally left blank 


\title{
INTRODUCTION
}

\author{
Toh Mun Heng
}

After 37 years as a nation, Singapore is at another important turning point of economic history: the challenge in enhancing and maintaining its competitive edge in the international economy. The international economy has also undergone fundamental changes during the last two or so decades. Economic activity is becoming not only more internationalised but also more significantly, it is becoming increasingly globalised in a world of increasing complexity, interconnectedness and mobility ${ }^{1}$. We live in a rapidly changing and increasingly competitive world in which global competition is making it essential for regional economies to develop the capacity and capability to make rapid adjustments to changing conditions if they are to remain competitive.

Globalisation has become a familiar theme in social sciences, particularly in the field of international economics. Globalisation can be defined generically as the growth of economic activity spanning politically defined national and regional boundaries. A number of forces are operating simultaneously to create a worldwide market in goods and services. The most important of these forces include: (1) technological diffusion, which allows a growing club of middleand even low-income countries to produce an increasing range of sophisticated products that were formerly monopolised by a few suppliers; (2) decreasing cost and increasing speed of transportation, especially by air freight, allowing world markets to be reached within a few hours; (3) increasing diffusion of information, accompanied by the movement of capital (FDI) to facilitate the development of complex networks of production across international frontiers; (4) declining trade barriers to trade through GATT or WTO agreements, and trade liberalisation initiatives by regional trade blocs such as the North American Free Trade Agreement and ASEAN Free Trade Agreement and international forum like APEC;

${ }^{1}$ More extensive discussion can be found in Dickens P. (1992) Global Shift: The Internationalisation of Economic Activity, New York: Guilford Press. 
and (5) government policies and behaviour such as the deregulation of financial or other markets, the lowering of barriers to competition, trade, and investment.

Concurrently, the scope of competition is no longer limited by national boundaries nor by the definition of a particular sector hence the term global. In essence, competition is about internalising on a worldwide scale key assets such as knowledge, finance, production experience and market access, that can lead to the development and to the effective commercialisation of a wide variety of product and services. As a small and extremely open economy, Singapore long term survival is very much dependent on the ability to maintain its viable position and remain afloat in the sea of global competition.

This book is intended to provide an intensive review of the several aspects of competitiveness in the Singapore economy. It is hoped that the present study will help to design an operational analytical framework to identify the strategies which will allow the economy to retain its competitive advantage in an increasingly globalised economic environment for the future years. It is a timely exercise in view of the fact that the international trading and investment climate has liberalised considerably, and the regional economies are achieving remarkable economic growth and development which begin to challenge Singapore's competitive edge as an regional transportation hub, international financial centre and a primary regional centre for technology and education. It is also a concerted effort of the academic community to complement the work of the government committee: Competitiveness of Singapore Committee (CSC) which will be releasing the report and recommendations in early 1998 . The current study on national competitiveness will be a continuation of the research effort of the researchers and targeted to yield useful findings, which will be of interest to policy makers as well as researchers interested in socioeconomic development strategies.

The chapters in this volume study will address the issue of national competitiveness from three perspectives:

(a) macro economic policies for continued growth and sustainability;

(b) micro-economic strategies for promoting and sustaining 
competitiveness in economic sectors: manufacturing, financial services; tourism, construction and others;

(c) the interface of social - cultural and economic dimensions on competitiveness.

\section{Brief Overview of Chapters}

In the first chapter, Tan Kong Yam and Toh Mun Heng provides a survey of factors which determine the competitiveness of firms and nations. A framework for competitiveness analysis is suggested. The importance of infrastructure facilities as a weapon of competition for city states is highlighted and the role of government in maintaining the nation's competitive edge is reviewed. It is recognised that the continued viability and prosperity of Singapore as a city-state nation will need it to be adaptable to ever changing competitive terrain in the world. It will have to vie for the development and status of a global city - a particular type of production site for the production of specialised services, for the production of financial innovations and making of markets. The oligopolistic structure of the world economy and increasing information content of production, coupled with a trend away from integration and mass production a la Ford and Taylor, and towards flexible networks of producers, implies that command and control functions become even more important, and these activities are apparently becoming concentrated in a decreasing number of cities and regions.

The strategic importance of technology in maintaining competitiveness is the theme of the second chapter authored by Lawrence Loh. It tracks the establishment of a dominant thinking in technology policy management within the country rooted on an economic imperative and highlights some observations in terms of technology inputs, throughputs and outputs. The chapter also articulates several challenges for Singapore's technology policy to strive beyond economic upgrading as an over-arching goal as well as to sharpen the focus on basic sciences. The use of information technologies and the ability to innovate in terms of products and process can be encouraged with appropriate policies implemented at a national and company level.

Singapore has won several accolades for being an efficient 
international transportation hub. In the third chapter, Tongzon Jose and Anthony Chin evaluate the current situation and consider measures in which Singapore's airport and seaport can further improve and maintain the competitive advantages nurtured over the years. The manufacturing sector has been a major locomotive of industrialisation and economic growth since Singapore obtained its Independence. Being flexible in adapting to an international trend of foreign investment and technologies, the manufacturing sector is responsible for about a quarter of the nation's GDP and is a major production base for electronic products in Asia. However, that its importance has not diminished over the years is due as much to continuous upgrading in the composition of industries as to the production processes and products. In Chapter 4, Wong Poh Kam presents a framework for identifying alternative routes the Singapore manufacturing sector can retain its catalytic role in economic development. It suggests the establishment of Singapore as a world product charter for selected niche products; as a "process technology transfer station" for the region and as a regional supply chain integrator, to further enhance the competitiveness of Singapore's manufacturing sector. Furthermore, the experience of successful high-tech firms in the four Asian NIEs of Korea, Hong Kong, Taiwan highlighted in the chapter can provide useful lessons for Singapore.

The construction sector is often considered as a sector with little opportunity for externalisation, and that it is technologically backward and low-skilled intensive. Contrary to this perception, the construction industry in its developed form can be an important foreign exchange earner and employer of professionals and technocrats. It is an industry which can provide high value-added jobs for the skilled workers and professionals like engineers, architects, lawyers and financial analysts. In Chapter 5, Toh Mun Heng discusses some major issues related to the restructuring of the construction sector to meet higher level of demand for efficiency and international competitiveness. These include the introduction of new management techniques, the problem of productivity improvement, the role of technology, the constraints pose by labour scarcity and the need for regionalisation and bidding for international contracts.

The tourism industry has been an important foreign exchange earner for Singapore since the 1960s. Over the years, the industry has 
undergone several structural changes in tandem with changing international demand and shifting consumers' tastes. However, the growth in the number of visitors coming to Singapore appears to be dwindling in the few years. Wong Poh Poh in Chapter 6 reviews the state of the tourism industry in Singapore. It examines the notion of New Age Tourism, regional tourism and other issues relevant to industry's competitiveness. Very much like the manufacturing industries, innovations in product, process, technology and management are required in the tourism industry to create growth and positive feedback effects on other sectors in the economy.

The development of Singapore as a world-class financial centre is critically assessed in Chapter 7. Lim Guan Hua, supported by evidence of international practices and rational arguments, puts forth several proposals for restructuring the financial sector in Singapore so as to achieve higher level of competitiveness and growth. Some of the strategies for sustaining and improving competitiveness in the industry include maintaining the distinction between domestic and offshore banking market; encouraging internet banking; merging finance companies with commercial banks; merging Sicom with SIMEX; and extensive liberalisation of the ways in which CPF moneys can be invested.

Despite the prominent presence and contribution of foreign companies to the national economy, there is still a substantial number of small and medium enterprises (SMEs) in the economy. Totalling about 80,000 , these SMEs function as an important bedrock for local entrepreneurship in the economy. The role of entrepreneurs and the importance of SMEs are reviewed in Chapter 8 by Bjerke Bjorn. Contrasting the Western practices of entrepreneurship with that found in Singapore, Bjorn provides a list of advice and suggestions that would improve the entrepreneurial environment in Singapore.

The social aspect of globalisation and competition is a much neglected area of study. In Chapter 9, Ho Kong Chong examines the effects of globalisation and its impacts on the social structure of Singapore society. The author considers whether Singapore's increasing embeddedness in the global economy, with the consequence of exposure to foreign culture and practices, development of contractual relationships and new social-cultural forms, would dampen the nation's competitiveness. 
Globalisation, massive technological change and international competition have led to greater emphasis on quality, and changes in the nature of work. In the final chapter of the book, William Koh considers how these pose new challenges for the human resource professionals in the way they carry out their traditional functions such as recruitment and selection, training and development, performance appraisal, pay and compensation, and career development.

The studies reported in this book are not the ultimate prognosis on the competitiveness of the Singapore economy. Nevertheless, it is sincerely hoped that they would encourage even more researchers and practitioners to explore in greater depth other competitive issues and strategies. Competitiveness of the Singapore economy is very likely to be a perennial concern for every Singaporean. 